\title{
Transactions of Human Organs According to Islamic Law, Positive Law and Health Law
}

\author{
Halimatus Khalidawati Salmah ${ }^{1}$, Tongat ${ }^{2}$, Mohammad Isrok $^{3}$ \\ \{halimatuskhsalmah@gmail.com ${ }^{1}$, tongat@umm.ac.id ${ }^{2}$, isrok@umm.ac.id ${ }^{3}$ \} \\ ${ }^{1,2,3}$ Master of Law Study Program, University of Muhammadiyah Malang, Indonesia
}

\begin{abstract}
Organ transplantation as an alternative in medicine has contributed to the increasing number of human organ transaction cases. This situation is a picture of a mismatch between law and reality in society. Therefore, the authors conducted research on this matter by observing Islamic law, positive law and health law. The method used is empirical legal research methods. The formulation of the problem namely; 1) What are the transactions of human organs in Islamic law, positive law, and health law? 2) What is the reality of the Indonesian people? With the results of the study; 1) All regulations in Indonesia forbid the existence of human organ transactions, whoever does it will be punished. 2) The high need for human organ transplants in health and the lack of donors, is one of the causes of high organ transactions. Meanwhile, other causes are economic pressure, lack of health facilities and special supervision provided to those who need donors. The conclusion of the research (suggestion and criticism) of the author is that in Indonesia in particular there must be institutions and special supervision for people who need and or want to donate their organs, socialization about health and the dangers of organ transactions, also real efforts to clarify the existing rules and economic improvement the community is very important to be considered and improved.
\end{abstract}

Keywords: Organ transactions, rules and reality.

\section{Introduction}

Every day society and technology in the world continues to develop rapidly, including the health sector. Various ways of treatment in the health sector also changed a lot. For example, in terms of saving lives from chronic or emergency conditions, transplantation is one of the most widely used treatment methods, this is happening in all countries including Indonesia [1]. Transplantation is one of the medical treatments that arises as a result of community unhealthy lifestyle, which then causes damage to the human organs. Transplantation defined as treatment by replacing old or damaged organs with new or healthier organs. Generally, patient who needs a transplant will wait for a donor, such as their relatives. Others also buy these organs from the black market because their lives are threatened and needs immediate donor.

The high demand for organs transplantation and tiny number of people who willing to donate their organs causes frequent cases of human organ transactions. The recipient continues to carry out the transplant despite the slight potential for success and recovery as well as requires a huge amount of money. For example, those who have diseases such as heart failure, kidney failure, eyes and so forth [2]. Including some ligament or nerve muscle tissue can be transplanted as well [3].

Patients who need urgent organ transplantation are usually ready to spent huge amount of money. When unfortunate people experience economic pressure, they prefer easy way to get money by donating their organs. In this case, the donor should be done voluntarily, whereas organ transactions carried out of compulsion. This should be banned because it does not meet the donor criteria set by the Indonesian Ulama Council (MUI).

The MUI helps countries by making rules, sanctions and criteria for prospective organ donors. In health ethics, doctors are also prohibited from serving organ transactions and there is a strict 
selection for prospective donors. However, organ transactions can still occur due to donor's financial difficulties factor, causing concern for the government and health practitioners. In some cases, recipients and donors can meet in person and make transactions. There are also transactions under the guise of transplants, openly offered to hospitals and at the most extreme, announced in social media forums. This phenomenon reflects the country's poor economic situation, lack of attention to health services, unclear rules and a lack of community sensitivity to the law. If this situation continues, not only the donor will be harmed, but also the country. Because when the citizen receives no prosperity, then the country's development is also hampered. Previous research illustrate that there are factors that causing mismatches between current rules and situation in the society. This research is expected to provide a solution.

\section{Methods}

This study uses an empirical legal research method, which functions to study the law in real terms, as well as knowing how law works in society. Empirical legal research examines people in social life, so it can be categorized as sociological legal research. The research material was taken from applicable legal norms and community data from various groups, levels of education and regions in Indonesia. It is hoped that the research results will depict legal and reality discrepancies in society in clearly, detail, systematically and easily understood by various groups.

\section{Research and Discussions}

\subsection{Transactions of Human Organs in Islamic Law, Positive Law, and Health Law.}

Islam is a religion that pays special attention to health. Every believer is obliged to look after and care for their bodies. Islamic law also discusses various diseases and ways of healing (the cure) in verses of the Qur'an, Hadits and the Islamic book of Jurisprudence or Fiqih. Islam also prohibits actions that are mudhorot (dangerous) physically. Some verses of the Qur'an that explain it are:

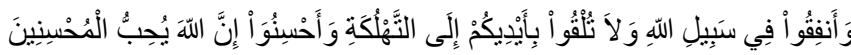

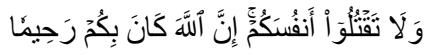

$$
\begin{aligned}
& \text { لاََ ضَرَرَ وَلا ضِرَار }
\end{aligned}
$$

Therefore, each individual must maintain their healthy body. In addition to the prohibition to do mudhorot (endanger) on himself, the faithful are also required to always cure his illness. A hadits says that all diseases have a cure. Narrated in a hadits shahih by Imam Bukhari.

$$
\text { مَا أَنْزَلَ اللهُ دَاءًا إِلَّا أَنْزَلَ لَهُ شِفِفاءً }
$$

Rasulullah Shallallahu 'alaihi wa sallam said: God does not send down a disease unless He also brings down the medicine. (HR. Bukhari) 
Some of the verses and hadiths above explain the command to protect the body and health. This is contrary to the phenomenon of human organ transactions. It is not halal for a Muslim to endanger himself or others in words or deeds without the right reasons.

Although the MUI has issued a fatwa on organ transplants, there is a dispute among the ulamas. Some of them believe that human organs are not allowed to change or taken. It is considered to change God's creation and to persecute humans. While we are not allowed to persecute ourselves and others. While the rest assume that for the sake of greater interests and problems, it is okay to do, as long as it is done in a good and right manner without the intention of the transaction (buying and selling) [4]. Despite the law that has been established by the ulemas, many cases of organ theft result in murder and or illegal organ transactions. This crime is organized and difficult to trace by law.

To reduce transactions for organ transplants, Islamic law stipulates that donors can only be obtained from someone who is still alive or corpse. For alive donors, syara law allowing to donate one or more organs from his body sincerely, without pressure from anyone (ikhlas).

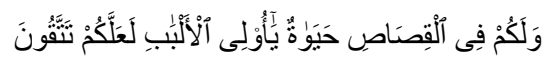

QS al Baqarah verse 179: People of understanding, there is life for you in retribution that you may guard yourselves against violating the Law.

Meanwhile, islamic theologian agreement is in accordance with Qs. Al-Maidah.

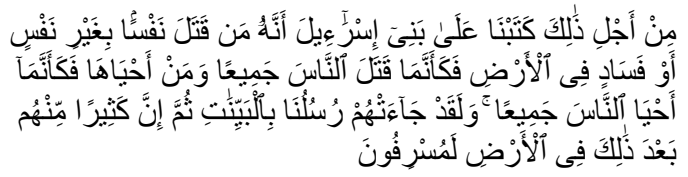

Qs. Al-Maidah. verse 32: Therefore We ordained for the Children of Israel that he who slays a soul unless it be (in punishment) for murder or for spreading mischief on earth shall be as if he had slain all mankind; and he who saves a life shall be as if he had given life to all mankind. And indeed again and again did Our Messengers come to them with clear directives; yet many of them continued to commit excesses on earth.

Several ijtihad results of MUI concerning human body namely Fatwa Result of National Conference MUI number 6/Munas VI/MUI/2000 concerning Human Rights, Fatwa MUI year 2019 concerning Transplantation of Organs and/or Body Tissues from Donors to Death to Others, as well as Fatwa MUI year 2009 concerning Eye Banks and Other Organs. Transplantation is not allowed, except to help because the mudhorot is smaller and intention tabarru' is not for transaction (buying and selling). The human body is considered only as entrusted by Allah Subhanahu wa-ta'ala. Human are only given the mandate to keep the entrusted body. A person has no right to give his organs because they are not private property. If there are other people who need another person's organs, it may be given if it is not life-threatening.

The importance of helping in virtue and piety and the prohibition of helping in making sin and transgression are explained in Al-Qur'an and hadits. Namely Al-Maidah verse 30 and 32 that state Allah forbid killing and whoever does it, he is among the losers. Ulema who refuse transplantation are due to the reason that changing or damaging without benefit is prohibited, but may done with the aim of greater benefit. People who are still alive are more entitled to use their limbs, so they are obliged to maintain their health. However, they have the right (ikhtisas) to give his organs voluntarily to others as long as it does not damage himself or cause a large mudharat.

Aside from corpse or someone who has died which their organs are no longer used. With good and correct provisions, donating the organs for others in need is permitted, as long as not for trading. 
The donor recipient must have strong reasons to conduct transplantation, such as live threaten. Donor process must be done with a will witnessed by the heirs.

Indonesia is an independent country and based on law. Based on Pancasila and the 1945 Constitution, with the aim of creating a nation that is just, prosperous, safe and orderly [5]. Strive to provide the same legal guarantees, not distinguishing anyone when enforcing the law [6]. In order to achieve this goal, various types of businesses are carried out, one of which is health development [7]. Indonesia is called state law when it uses the rule of law when carrying out its affairs in order to create law order in society [8]. These statements have been illustrated in the opening of the 1945 Constitution.

Transactions of organs in Indonesia are considered illegal acts that are contrary to the ideals of the nation. Generally, those who carry out organ transactions are people who have conditions that are less able. Whether it's like a physical, psychological or economic problem. Organ transactions are a criminal offense. But it turns out that in the Criminal Code the regulation on organ transactions does not exist, so it is categorized in a special criminal group.

The Criminal Code does not regulate human organs transactions, but regulates life-threatening goods transaction. Article 204 of the Criminal Code contains criminal sanctions for anyone who trades goods that are known to endanger the life and/or health of others. Article 206 of the Criminal Code is supplemented by additional penalties and announcements of judge decisions [9]. While Article 64 paragraphs 1 and 2 of Law No. 36 of 2009 regulates the healing and recovery of diseases caused by organ transplants. This article also explains humanity in paragraph 3 as transaction of human organs is prohibited and its criminal sanctions described in article 192 [10].

Unlike the case with organ transplants. Organ transplantation defined as moving (graft) a tool or tissue of functioning and healthy human body to replace the recipient's organ that no longer functioning in terms of treatment or as an effort to rescue the recipient. Until now, transplantation is the best way to help patients who have organ damage [11]. Unfortunately, organ transplantation opens the opportunity to crime of selling illegal organs due to its high demand and urgency. This needs to be taken seriously considering human organs are not goods that can be traded freely because they can threaten the lives of others. When it happens on a large scale, it may impact on the unity of the Republic of Indonesia.

Unfortunately, in Criminal Code and Law No.36/2009 concerning Health has not yet explained the action described as the practice of human organ transactions. However, Law No.23/1992 concerning Health regulates the prohibition of human organs commercialization. Article 33 Paragraph (2) states that organ transplants and blood transfusions are done only for humanitarian purposes and are prohibited for commercial purposes. Violations of these articles are subject to prison sentence for 15 years maximum and a maximum fine of Rp. 300 million [12]. According to Law No. 36 of 2009 concerning Health Article 64 is explained as follows: (a) Healing of diseases can be done through body transplants and drug implants. (b) Organ transplants as referred to in paragraph (1) are carried out only for humanitarian purposes and are prohibited from being commercialized. (c) Organs trading are prohibited under any circumstances [13]. Article 69 regulate that every person who intentionally trades organs or body tissues under any circumstances, as referred to in Article 64 paragraph (3), is sentenced to a maximum of 10 years in prison and a maximum fine of Rp1,000,000,000.00 (one billion rupiah) [14]. Therefore, positive laws only permit human organ transplantation for humanitarian purposes and prohibited from being commercialized.

The practice of kidney organ trafficking for medical transplants is still common. It is difficult to get kidney organs from living donors without reward, so kidney organs are on high demand. There are no laws and regulations that protect recipients and providers of transplanted organs, in terms of receiving or giving rewards as appreciation. Fundamental problem occurs in its regulation of organ transplantation terms and mechanisms. On the one hand, it is permissible as long as for the treatment and recovery of Health and only for humanitarian purposes, but is prohibited for commercial purposes. Unfortunately, humanitarian and commercial goals are not clearly regulated. The method of obtaining organs and or tissues of the body is also not regulated. Ironically, the provisions for the sale and purchase of organs and tissues of the human body have the threat of criminal sanctions that are relatively heavy for perpetrators. But if traced, it happens because of compulsion. 
Organ transplants should not be linked to organ transactions because they would violate the MUI fatwa and positive law. There are four legal terms of the agreement according to Article 1320 of the Civil Code namely; their agreement is binding, the ability to make an agreement, a certain thing, and a halal cause. If referring those terms, organs transaction is invalid or illegal, with greater mudhorot if the seller is still alive.

Frequently, donor recipients give money to the donors because of reciprocation. Lack of organ donors causing patients who need adequate health services to protect themselves find their own ways to solve their problems. Some experts say organs transactions occur because the lawsuits are rare and through untraced black-market channels. Patients should obtain legal protection. According to the 1945 Constitution, the state has duties to protect and maintain health, justice and welfare of the citizens.

Human organs transplantation was first done successfully on December 23rd 1954, this method has become increasingly popular. However, when organ transplantation needs increased, then problem has arisen like lack of donors. It opens up opportunities for people who want to make a profit by providing or even selling their own organs. Moreover, patients are willing to give extra cash to get the organs regardless of its origin. WHO data states that organs trafficking often involve black markets. The hospital has conducted rigorous donor screening, but there is no guarantee that donor recipients will not look for people who want to sell their organs under the guise of donors on the black market. Human organs, especially kidneys, become the main commodity of black-market sales [15].

Kartono, an initiator of the MKEKI and a former chairman of IDI, revealed that doctors have the opportunity to conduct organ transactions in the form of information on patient needs to the brokers. Doctor's involvement occurs indirectly so that it is difficult to trace. Penal sanctions do not threaten them as well, only ensnare the person making the transaction. In this case, doctor will be subject to ethical sanctions. Health Law No. 36 of 2009 rule it in limited to articles relating to criminal acts. Namely Article 64 paragraph 1-3, Article 65 paragraph 1-3, Article 66, 67 paragraph 1 and 2, and Article 192. Despite those regulations, when patient urgently needs the organs but hospital cannot help to obtain it as soon as possible, donor recipients or their family will look for people who willing to sell their organs. Thus, the opportunity for organs transaction once again is opened. The Regulations often hamper law enforcement officers in eradicating cases, because they only regulate normative matters. So that witnesses and evidence are difficult to obtain because the authorities experience obstacles outside the legal system, such as crime mode, subjects and object [16].

\subsection{Reality of The Indonesian People.}

Despite the religious law, positive law and several articles of health law already prohibited organs trafficking, health community cannot avoid its chance occurrence during organs transplantation. To gather public opinion about this phenomenon, 133 respondents gave their statements on the questionnaire. In order to representing the whole society equally, respondents gathered are varies from age 16 to 60 years old, have various fields of profession, level of education and social status. Therefore, this research able to accommodate all thoughts and foresee knowledge development regarding this issue in the society.

The majority of Indonesian as much as $96.2 \%$ have understood the importance of health. $3 \%$ of them still confused and $0.8 \%$ answered not knowing. $79.7 \%$ of the public know and have seen a news about human organs transaction, quarter of them $(20.3 \%)$ answered they did not know. Only $79.9 \%$ people understood regulation relating human organ transactions in Indonesia. The remaining $21.1 \%$ did not know the rules. Regarding the ban, $57.9 \%$ said that they thought it might still be true, and $39.1 \%$ of respondents answered yes. Considering the highly needs of donors, only a few people who voluntarily willing to donate, the rest $3 \%$ assume there isn't.

Regarding trigger on illegal transactions of human organs, the reasons that are written based on most opinions respectively are;

1) Inadequate economy to survive makes people often choose ways to gain money. This factor caused by difficulty to get a job, the high number of layoffs and high debt. 
2) Numerous and urgent needs from patients as well as difficulty to get donors that comply with existing regulations. The state also does not fully guarantee organ stock availability. So that people are willing to pay dearly to get it, either by buying on the black market or paying someone who wants to sell their organs. Unfortunately, people with lower income often take this shortcut.

3) Health factors. It is triggered community awareness who know their body condition or disabilities. So that they choose to donate their organs to those in needs and have longer life expectancy.

Around $30 \%$ of respondents thought that the government also had not yet made a specific regulation toward human organ transaction. All this time, the regulation on organ transactions are scattered in several articles of the existing law. This inefficiency put people to examine several laws to know one prohibition. In the existing articles, it has not yet been explained regarding special regulatory body for transactions of human organs. There is also no specific institution that focuses on providing donors, other than the Eye Bank which provides legal donor eyes. That phenomenon creates public perception that it is okay to get illegal organs as long as the live is saved. The mislead public opinion become the main cause of human organ transactions.

General public as respondent assume that majority illegal organs seller are from the unfortunate and the buyers are the rich who needs donor. The black market and doctors are also suspected as the perpetrators in illegal organ transactions. In handling or preventing this case from happening, 63.9\% of respondents thought the government had ran the regulations and carried out their duties properly. However, the remaining $36.1 \%$ believe that law enforcement officials had not yet applied the existing rules properly and correctly. Organ trafficking is a special organized crime so that it is difficult to completely eradicate unless the government creates specific rules. When experiencing organs trafficking, people tend to be afraid to report or are confused about where to report due to some reasons. Namely, lack of government socialization, lack of religious education and health, psychological health and the community and family environment.

Some countries create Organ Banks to overcome the problem of organ trafficking in their countries. Organ Bank is a special organization accompanied by a special supervisory team that accommodates and provides organ supplies. The organ bank functions as a legal dealer and supplier of organs. In the questionnaire, majority of respondents agreed with its holding in Indonesia to reduce organ trafficking. Both respondents who refused and agreed with Organ Bank are requesting good and honest regulation and supervision in management, so that it could benefit not only individuals but also the state.

\section{Conclusion}

Judging from all sides both Islamic law, positive law and health law concluded that, transactions of human organs are prohibited. Anyone who carries out or is related to human organ transactions, for whatever reason will be subject to severe sanctions. But there are no regulations that specifically regulate the actions of organ transactions, some existing rules are still in the form of articles scattered in several laws that are considered to be related and until now the regulation and supervision of human organ transactions has not been fully as expected. Because, both in the Criminal Code and Law No. 36 of 2009 concerning Health, there is no article that shows the characteristics of what and how are the characteristics of an action that is categorized in the transactions of human organs. In general, transactions of human organs in Indonesia are prohibited, unless done voluntarily. But in fact many patients have difficulty finding donors, and the country does not have enough stock. This causes many people to carry out organ transactions, either through the black market or meet directly with donors by promising some amount of money. This crime is the same as human trafficking, both are organized crime so it is difficult to catch the suspect or the person who committed the Act.

Meanwhile, when viewed in the reality and public opinion regarding this matter, there are still gaps in the rules made by the government.The suggestion and criticism from the author is that in Indonesia in particular there must be institutions and special supervision for people who need and or want to donate their organs, socialization about health and the dangers of organ transactions, also 
real efforts to clarify the existing rules and economic improvement the community is very important to be considered and improved. so that even the poor will not easily sell their organs just for money.

\section{Acknowledgments}

The author say to thank you for the head UNNES and UMM for providing a facility to join Internasional Conference on Legal Studies (ICILS).

\section{References}

[1] Arifahrial.: Transplantasi dan Jual Beli Organ. Dikutip dari https://staff.blog.ui.ac.id diakses pada hari Kamis, 7 November 2019. Jam 21. 48 WIB.

[2] Agustina, Bunga.: Kewenangan Pemerintah Dalam Perlindungan Hukum Pelayanan Kesehatan Tradisional Ditinjau Dari UU RI No. 36. Tahun 2009 Tentang Kesehatan. Jurnal Wawasan Yuridika 32. No. 1 (2015).

[3] Aristantie, Desie Widya (Eds).: Perjanjian Antara Pendonor dan Pasien Yang Membutuhkan Ginjal Untuk Transplantasi (Analisis Pasal 64 UU RI No. 36 Tahun 2009 tentang Kesehatan). University of Brawijaya: Malang. (2014).

[4] Kamila, Anita dan M. Rendy.A.: Kajian Terhadap Penyelesaian Sengketa Pembagian Harta Waris Atas Tanah Akibat Tidak Dilaksanakannya Wasiat Oleh Ahli Waris Dihubungkan Dengan Buku II KUHPer Tentang Benda (Van Zaken). Jurnal Wawasan Yuridika 32. No. 1 (2015).

[5] Marpaung, Leden.: Asas-Teori-Praktik Hukum Pidana. Sinar Grafika: Jakarta (2005).

[6] Mahasena, Adhyaksa.: Pertanggung Jawaban Pidana Bagi Pelaku Tindak Pidana Jual Beli Organ Tubuh Manusia. Jurnal Magister Hukum Udayana. Vol. 7 No. 1 (2018).

[7] Nuraeny, Henny.: Penyuluhan Hukum Mengenai UU No. 21 Tahun 2007 Tentang Pemberantasan Tindak Pidana Perdagangan Orang Bagi Guru Pembimbing Konseling dan Siswa atau Siswi SMK/SMA/MA Se-Kabupaten Cianjur. Journal of Empowerment. Vol. 1, No. 1 (2017).

[8] Syaifullah.: Transplantasi Organ Tubuh: Perspektif hukum Islam, Positif dan Etika Kedokteran. Al-Mursalah. Vol. 2 No. 1 (2016).

[9] Susanto, Agus.: Reformulasi Kebijakan Tentang Transplantasi Organ Ginjal Manusia. Jurnal Ilmiah Dunia Hukum. Vol. 3 No. 2 (2019).

[10] Soetjipto, Patricia.: Please Know that Any Use Or Reproduktion of Content Must Systematically and Clearly State the Following Copyright. Naskah Akademik. Jakarta: Universitas Indonesia (2010).

[11] UUD 1945

[12] UU No. 36 Tahun 2009 Tentang Kesehatan

[13] Fatwa MUI No. 12 Tahun 2019 Tentang Transplantasi Organ dan atau Jaringan Tubuh Dari Pendonor Mati Untuk Orang Lain.

[14] Gani, Ruslan Abdul dan Yudi Armansyah.: Penegakan Hukum Kasus Jual Beli Organ Tubuh di Indonesia. Jurnal Fenomena. Vol. 8 No. 2 (2016).

[15] Iqbal, Muhammad.: Perkembangan Kejahatan Dalam Upaya Penegakan Hukum Pidana : Penanggulangan Kejahatan Profesional Perdagangan Organ Tubuh Manusia. Prosiding Seminar Nasional Pascasarjana Univ. Pamulang (2017).

[16] Paminto, Saptaning Ruju.: Dehumanisasi Penjualan Organ Tubuh Manusia Berdasarkan Hukum Positif. Jurnal wawasan yuridika. Vol.1 No. 2 (2017). 